\title{
9. Sınıf Fizik Ders Kitaplarında Kullanılan Örnek Türlerinin Karşılaştırılması: Enerji Ünitesi*
}

\section{Comparison of Example Types Used in 9th Grade Physics Textbooks: The Energy Unit}

\author{
Özgül KAYA**, Sevilay ALKAN***
}

\begin{abstract}
Öz: Bu çalışmada 9. sınıf fizik ders kitaplarında enerji ünitesinde yer verilen örnek türlerinin tespit edilmesi amaçlanmıştır. Enerji ünitesinde kullanılan örnek türleri Alkan (2016) tarafından geliştirilen ve başlangıç, standart, geliştirici, örnek dışı, uç ve karşıt örneklerden oluşan sınıflandırmaya göre analiz edilmiştir. Çalışmanın yöntemi doküman analizi olup doküman olarak 2018-2019 eğitim-öğretim yılında fizik dersi için Talim ve Terbiye Kurulu Başkanlığı tarafindan uygun görülen ve öğretime sunulan iki ders kitabı incelenmiştir. Birinci ders kitabında (DK1) enerji ünitesinde 65 örnek tespit edilmiştir. Bu örneklerin 35'i başlangıç, 21'i standart, 24'ü geliştirici, 3'ü örnek dışı ve 5'i de karşıt örnek türlerine ait olduğu belirlenmiştir. İkinci ders kitabında (DK2) ise 62 örnek tespit edilmiş olup bu örneklerin 27'si başlangıç, 9'u standart, 32'si geliştirici, 4'ü örnek dışı ve 4'ü karşıt örnek türlerine ait olduğu görülmüştür. Bu iki ders kitabında da uç örneklerin yer almadığı tespit edilmiştir. 9. sınıf düzeyi öğrencilerin fizik öğretimine giriş yaptı̆̆ı düzeydir. Bu bakımdan başlangıç ve standart örneklerin sayısının fazla olması beklenen bir durumdur. Fizik öğretim programında yer alan diğer ünitelerdeki konularında, örnek türleri açısından incelenmesi ve okullarda kullanılması uygun görülen fizik ders kitaplarının bu açıdan karşılaştırılması tavsiye edilir.
\end{abstract}

Anahtar Kelimeler: Fizik ders kitabı, enerji ünitesi, örnek türleri.

\begin{abstract}
In this study, it is aimed to determine the example types used in the energy unit in the 9th grade physics textbook. Example types used in the energy unit were analyzed according to the classification developed by Alkan (2016) and consisting of startup, standard, improving, non-example, extreme and counter examples. The method of the study was document analysis and two textbooks that were approved by the Board of Education and Discipline for the physics lesson in the 2018-2019 academic year were examined. 65 examples were identified in the energy unit in the fisrt textbook (TB1). It was determined that 35 of these examples belong to startup, 21 to standard, 24 to improving, 3 to non-example and 5 to counter example types. In the second textbook (TB2), 62 examples were identified and it was observed that 27 of these examples belong to the startup, 9 to standard, 32 to improving, 4 to the non-example and 4 to counter example types. It has been determined that there are no extreme examples in either of these two textbooks. The 9th grade is the level at which students enter physics teaching. In this respect, it is expected that the number of initial and standard examples to be high. It is recommended to examine the subjects of other units in the physics curriculum in terms of example types.
\end{abstract}

Keywords: Physics textbook, energy unit, example types.

\section{Giriş}

İnsanoğlu yazıyı bulduktan sonra keşfettiği ve öğrendiği yeni şeyleri unutmamak, muhafaza etmek, geliştirmek ve kendinden sonraki nesillere tecrübelerini ve bilgilerini aktarabilmek için yazı yazabileceği materyaller aramıştır. İlk çağlarda, taş ve madenlere daha sonra tahta ve killere, ipeklere, papirüslere ya da derilere yazmışlardır. Bilginin nesiller arasında aktarılmasında kullanılan en temel ve kalıcı araçlardan biri kitaplardır (Adıbelli, 2007). Özellikle ders kitaplarının, bilginin aktarılması sürecinde, öğrenmenin kontrol edilmesi açısından önemli bir materyal olduğu ifade edilebilir. Ders kitapları öğretim programlarının hedeflerini gösteren somut bir resim, sınıf içi öğretimde önemli bir öğretim aracı olması

\footnotetext{
*Bu çalışma, 1. Uluslararası Fen, Matematik Girişimcilik ve Teknoloji Eğitimi Kongresi’nde (İzmir, 2019) sözlü bildiri olarak sunulmuştur.

**Sorumlu yazar, Dr., TED Mersin Koleji, Mersin-Türkiye, ORCID: 0000-0001-7659-7980, e-posta: ozgulkaya33@gmail.com

***Dr., Milli Eğitim Bakanlığı, Trabzon-Türkiye, ORCID: 0000-0002-6918-3832, e-posta: svlyalkn@ gmail.com
} 
(Yılmaz, Seçken ve Morgil, 1998) ve tüm okullar düzeyinde öğretmen ve öğrenciler arasında köprü işlevi görmesi bakımından önemli bir yere sahiptir (Alkan ve Güven, 2018). Özellikle öğretim programının takip edilmesinde ve öğretme sürecinde, öğretmen ve öğretim programı arasında bir arabulucu işlevi görür (Başer, 2012; Viholainen vd., 2015).

Ders kitaplarının öğretmen ve öğrencilere sağladığı birçok yarar vardır. Öğretmenler açısından, dersin hedefleri, öğretim yöntem ve teknikleri, ders içinde uygulanacak testler ve ödevler hakkında fikirler verir (Kavcar ve Erdem, 2017). Başka bir ifade ile ders kitapları özellikle deneyimsiz öğretmenlere neyi, ne zaman ve nerede yapabileceklerine dair yol gösterir (Dayak, 1998). Bu anlamda ders kitaplarının öğretmenler için bir pusula görevi gördüğü ifade edilebilir. Öğrencilerin ise kendi başlarına öğrenmelerine, öğrendiklerini tekrar etmelerine ve konular arasındaki ilişkileri görmelerine imkan sağlar (Kılıç ve Seven, 2002). Öğretmen ve öğrenciler için ders kitaplarının kullanılmasının temelde üç önemli nedeni vardır. Bunlar ders kitaplarının öğretim programının bir yansıması olması, öğretim materyali olarak kullanılması ve programa göre içeriğin izlenmesiyle birlikte çalışma ve ödevlendirme kolaylığına sahip olmasıdır (Taş, 2007). Ders kitaplarının kullanım amaçlarına göre kitapların hazırlanmasında öğretim programına bağlı kalınmasının yanı sıra görsellik, içerik, fiziksel yapı, dil ve anlatım gibi tüm özelliklerin de göz önünde bulundurulmasının önemli olduğu görülmektedir (Kavcar, 2012). Öğrencilerin işlenen konuları kendi kendilerine, doğru ve sıralı bir şekilde öğrenmelerini sağlayan (Duman vd., 2001) ders kitaplarında, verilen bilgiler öğrencilerin zihinsel gelişimine uyum sağlamalı ve konular somuttan soyuttan, basitten karmaşığa, kolaydan zora doğru sunulmalıdır (Dayak, 1998; Esirgemez, 1995; Gün, 2009; Sadoski, 2001). Özellikle öğrencilerin öğrenme, öğretmenlerin de ders içi uygulama aracı olan ders kitaplarında içerik açısından konuların sunumu, etkinliklerin uygunluğu (öğrenci seviyesi ve konuya) ve kullanılan örneklerin çeşitliliği kavramların daha iyi anlaşılması açısından önemlidir.

Örnek vermek, etkili bilim ögretiminin merkezinde yer alan bir uygulamadır (Oliveira ve Brown, 2016). Fizik dersi, fen bilimleri dersleri arasında konuları itibariyle anlaşılması ve anlatılması zor olan derslerden biridir (Bozkurt ve Sarıkoç, 2008). Konuların daha anlamlı öğretilebilmesi için öğrenme ortamlarında öğrencilerin önbilgilerinin dikkate alındığı, günlük yaşamdan aktarımların yapıldığı, kavramlar arası geçişin anlamlı olduğu, kavramlar ve olaylar arası ilişkilerin vurgulandığı (Ayvacı ve Deveci, 2013) örnek ve örnek çeşitlerinin sunulmasının fizik dersinin öğrenilmesinde önemli olduğu düşünülmektedir. Örnek, kavramlara ait tanımlarla birlikte kavramlara ait olmayan durumların da açılanması, kuralların veya ilkelerin anlamlarının açıklanmasında ve bu durumlara ait prosedürlerin uygulanma biçimlerinin ifade edilmesinde kullanılan özel durumlardır (Alkan, 2016). Örnekler, kişilerin sosyal deneyimlerini etkileyebilir ve üzerlerinde kalıcı bilişsel ve duygusal etkiler yaratabilir (Oliveira ve Brown, 2016). Örnekler, zihnimizdeki soyut kavramları somut bir yapıya dönüştürererek bu kavramların daha iyi anlaşılmasına yardımcı olur (Gökbulut, 2010). Bunun yanı sıra tanımların ve kuralların anlaşılmasında, matematiksel ifadelerin sınıflandırılmasında ve benzerlik gösteren durumların ilişkilendirilmesinde önemli bir rol oynayarak kavrama ait bilgilerin daha anlamlı olmasına yardımcı olur (Watson ve Mason, 2002). Bununla birlikte örnekler, kavrama ait olmayan durumları da ortaya koyarak oluşabilecek kavram yanılgılarını engelleyebilir (Alkan, 2016). Örnek türleri ile zenginleştirilmemiş bir ortamda kavramların anlaşılması zor olabileceği gibi tek bir örnek çeşidinin de her zaman kavrama ait bütün anlam ve özellikleri ifade etmesi güçtür (Alkan, 2016; Alkan, Güven ve Y1lmaz, 2017; Alkan ve Güven, 2018). Mesela, enerji ünitesinde yer alan kavramlar içerisinde sadece iş kavramına ilişkin verilmiş bir örneğin, enerji kavramının tüm özelliklerini taşıdığı söylenemez. Bu örnek enerji kavramının anlaşılmasında önemli bir rol oynayacağı gibi o kavramı tamamen temsil edemez. Bu bağlamda örnekler, kullanım amaçlarına ve yerlerine göre değişiklik göstermektedirler. Bu doğrultuda çeşitli araştırmacılar tarafından farklı örnek sınıflandırmaları yapılmıştır (Alkan, 2016; Bills, Mason, Watson ve Zaslavsky, 2006; Michener, 1978; Polya 1981, akt. Watson ve Mason, 2005). Bu araştırmacılardan Alkan (2016), örnekleri başlangıç, standart, geliştirici, uç, örnek dış1 ve karşıt 
örnekler olarak sınıflandırmıştır. Başlangıç örnekleri bir konuya başlarken öğrencilerin dikkatini çeken, eski konularla bağlantı kuran ve konu için gerekli olan bilgileri içeren örneklerdir. Standart örnekler konuda geçen tanımların, kuralların ve işlemsel süreçlerin ifade edildiği öncül örneklerdir. Standart örneklerle ögrencilere sunulan tanımların farklı durumlara uygulanması geliştirici örneklerle sağlanmaktadır. Geliştirici örneklerle birlikte kavramın sınırları daha fazla genişletilebilir ve kavramlar arası ilişkiler sağlanabilir. Bununla birlikte öğencilerin düşünme ve akıl yürütme becerileri geliştirilebilir. Uç örnekler kavramların istsinai durumlarını ortaya koymaktadır. Kavrama ait istisnai durumlar ortaya konularak öğrencide kavramın sınırları belirgin hale getirilmeye çalışılır. Örnek dışı örnekler tanıma ya da verilen kurala ait olmayan durumları ifade etmek için kullanılırken, öğrencilerin yanlış genellemeler yapmalarını engellemek için de karşı örnekler kullanılmalıdır.

Ders kitaplarının görsel tasarımı, eğitsel özellikleri, dil ve anlatımı açısından istenilen uygunlukta olması, birçok dersin eğitiminde olduğu gibi fizik dersinin eğitiminde de öğretmen, öğrenci ve eğitim teknolojileri açısından öğretim-öğrenmedeki başarıyı etkileyen faktörlerdendir (Adıbelli, 2007). Ayrıca öğretmenlerin ve öğrencilerin büyük bir kısmının öğretme-öğrenme ortamının gerçekleştiği zaman diliminin çoğunda ders kitaplarından yararlandıkları bilinmektedir (Karamustafaoğlu, Yaman ve Karamustafaoğlu, 2005). Birçok araştırmacı fizik ders kitaplarını içerdiği deney türleri, etkinlikler, bilimsel süreç becerileri, öğretim programı kazanımlarına uygunluğu açısından değerlendirmiştir. (Aktamış, Feyzioğlu, Özenoğlu-Kiremit ve Delioğlu, 2010; Çepni, Ayvacı, Şenel-Çoruhlu ve Yamak, 2014; Eke, 2013; Senem ve Eryılmaz, 2015). Bununla birlikte fizik ders kitaplarında yer alan örneklerin ve örnek türlerinin var olan değerlendirmeler içinde yer almadığı görülmüsşür. Öğrencilerin derslerde başarısız olmalarının nedenleri arasında ders kitaplarında kullanılan ifadelerin anlaşılmaz olması, günlük hayatla ilişkilendirilmemesi ve kullanılan örneklerin karmaşık olması yer almaktadır (Göze, 1999; Işık, 2003; Işık, 2008; Özgen, 1993). Milli Eğitim Bakanlığı (MEB), Talim ve Terbiye Başkanlığının (TTKB) 28 Mart 2018 tarih ve 6410086 sayılı kararı ile birlikte Ders Kitapları ve Eğitim Araçları Yönetmeliği (9/1b; 9/1ç; 10/1b; 10/1ç) öğrencilere davranış, bilgi ve beceri kazandırılırken onların sınıf düzeylerine uygun kavram ve örneklerden yararlanılması gerektiğini belirtmektedir. Bu bakımdan ders kitaplarında yer alan örnek türleri açısından ders kitaplarının değerlendirilmesi, öğrencilerin örnekler aracılığıyla konuları öğrenmesi ve öğretmenlerin de konuların öğretimi esnasında kullanacakları örnek ve örnek türleri açısından iyi bir yol gösterici olması bakımından önemli görülmektedir. Bunun yanı sıra ders kitaplarında kullanılan örnek türlerinin incelenmesinin örneklerin çeşitliliği ve öğretimdeki gücüne ilişkin ders kitabı yazarlarına yardımcı olacağı düşünülmektedir. Öğretim programları doğrultusunda geliştirilen ders kitaplarının eğitim-öğretim faaliyetlerinin geliştirilmesi ve öğrencilerin anlamlı öğrenmesine katkı sağlayacak biçimde tasarlanması gerekmektedir. Bu durumlara bağlı olarak ders kitaplarında yer alan, anlamlı öğrenme ve öğretmeyi sağlayacak olan en temel araçlardan biri olan örnek ve örnek türlerinin incelenmesi de önemli bir problem olarak ortaya çıkmaktadır. $\mathrm{Bu}$ anlamda ders kitaplarındaki örnek türlerinin belirlenmesi ve bu bağlamda ortaya çıkan noksanlıkların düzeltilmesi önemli görülmektedir.

Bu bilgiler 1şığında bu çalışma ile 9. sınıf fizik ders kitaplarında enerji ünitesinde yer alan örnek türlerinin kazanımlar doğrultusunda incelenmesi amaçlanmıştır. Enerji, tüm bilimleri kapsayan birleştirici bir kavram olmakla birlikte, çevre ve yakıtların kullanımı gibi sosyal alanlarda temel öneme sahip olma özelliğini de taşımaktadır. Çocuklar enerji kavramıyla günlük hayatlarında küçük yaşta karşılaşırlar ve bu kavramla ilgili ön bilgiler edinirler. Okulda ise fiziksel olarak enerji korunumu ile karşı karşıya kalırlar (Frankowicz vd., 2008). Lise düzeyinde 9. sınıftan itibaren derslerin içeriğinde yer alan enerji kavramı üniversitede ve günlük hayatta da öğrencilerin karşısına çıkmaktadır. Bu bakımdan öğrencilerin enerji kavramını doğru bir şekilde yapılandırmaları oldukça önemli görülmüştür (Madanoğlu, 2015). Ayrıca öğrencilerin enerji ünitesindeki kavramlara ilişkin karmaşa yaşamaları (Aydın ve Balım, 2005; Aydoğmuş, 2008; Ayvac1 ve Devecioğlu, 2009; Ergin, 2011; Erduran Avc1, Kara ve Karaca, 2012; Kurnaz, 2011) 
ve enerjiye ilişkin kavramların ileride yer alan üniteler için ön bilgi niteliğinde olması (Madanoğlu, 2015) bakımından enerji ünitesindeki örneklerin incelenmesinin önemli olduğu düşünülmektedir.

\section{Yöntem}

$\mathrm{Bu}$ çalışmada araştırmanın amacına uygun olarak doküman analizinden yararlanılmıştır. Doküman olarak 2018-2019 eğitim-öğretim yılında 9. sınıf fizik ders kitabı olarak okullarda okutulması uygun görülen iki ders kitabı incelenmiştir. Bu anlamda çalışmada karşılaştırılan kitaplar, birinci ders kitabı (MEB, 2018a) DK1 olarak kodlanırken ikinci ders kitab1 (MEB, 2018b) DK2 şeklinde kodlanmıştır. Bu çalışma, bilimsel araştırma ve yayın etiğine aykırı eylemlerde bulunulmadan hazırlanmıştır.

\section{Verilerin analizi}

Dokuzuncu sınıf fizik ders kitaplarında enerji ünitesinde yer alan örneklerin türlerinin belirlenilmesinde Alkan (2016) tarafından geliştirilen örnek türlerine ait sınıflandırma kullanılmıştır. Alkan (2016) örnekleri başlangıç, standart, geliştirici, örnek dışı, uç ve karşıt örnekler olmak üzere altı farklı kategoriye ayırmıştır. Bu kategorilere ilişkin açıklamalar Alkan ve Güven (2018) tarafindan bir tablo şeklinde sunulmuştur (bkz. Tablo 1). Tablo 1'in kullanımı için araştırmacılardan gerekli izin ve onay alınmıştır. Çalışmada verilerin analizi için tercih edilen bu sinıflandırma, diğer araştırmacılar (Bills, Mason, Watson ve Zaslavsky, 2006; Michener, 1978; Polya 1981, akt. Watson ve Mason, 2005) tarafindan geliştirilen sınıflandırmalar ile kıyaslanarak oluşturulması ve bu sınıflandırmanın kapsamının geniş olması ve her bir örnek türünün tespit edilmesi adına belirli özelliklerinin açıklaması nedeni ile tercih edilmiştir.

Tablo 1

Örnek Kategorileri, Kodlar ve Kullanım Amaçları (Alkan ve Güven, 2018, s.150)

\begin{tabular}{ll}
\hline Örnek Kategorileri & Örneklere Ait Kodlar \\
\hline \multirow{2}{*}{ Başlangıç örnekleri } & Konuya öğrencilerin dikkatini çekme ve hatırlatma (B1) \\
\cline { 2 - 2 } & Tanım için alt yapı oluşturma (B2) \\
\cline { 2 - 2 } Standart Örnekler & Konular arası ilişkiyi sağlayarak konuya giriş yapma (B3) \\
\cline { 2 - 2 } & Kuralı yansı̈tma (S2) \\
\cline { 2 - 2 } & Bir prosedürün nasıl uygulandığını gösterme (S3) \\
\hline \multirow{3}{*}{ Geliştirici Örnekler } & $\begin{array}{l}\text { Tanımın standart örneklerinin öğrencilerde oluşan muhtemel algıyı } \\
\text { genişletmeye çalışma (G1) }\end{array}$ \\
\cline { 2 - 2 } & $\begin{array}{l}\text { Kuralı yansı̈an standart örneklerin dışında bu kuralın başka durumlarla } \\
\text { ilişkisini gösterme (G2) }\end{array}$ \\
\cline { 2 - 2 } & Konular arası ilişkiyi sağlayarak kavramın sınırlarını genişletme (G3) \\
\hline Uç Örnekler & Kavramlara ait istisna durumları gösterme (U1) \\
\hline Örnek Dışı Örnekler & Tanıma ait olmayan durumu gösterme (ÖD1) \\
\cline { 2 - 2 } & Kurala ait olmayan durumu gösterme (ÖD2) \\
\hline Karşıt Örnek & Öğrencilerin yanlış genellemelere ulaşmalarını engelleme (K1) \\
\hline
\end{tabular}

Bu çalışmada ders kitaplarında kullanılan örnek türleri enerji ünitesine ait her bir kazanım için tek tek incelenmiştir. Bu doğrultuda ders kitabında bu ünitedeki kazanımlar Tablo 2'de sunulmuştur. Enerji ünitesinde yer alan örnekler; örnek ve örnek türleri hakkında gerekli bilgiye sahip iki farklı araştırmacı tarafından kodlanmıştır. Farklı araştırmacıların kodlamaları ile kıyaslanmıştır. Kodlamaların güvenirlik hesaplamasında Miles ve Huberman'ın (1994) tavsiye ettiği güvenirlik formülü kullanılmıştır. Bu formüle göre çalışmanın güvenirlik yüzdesi 0,82 bulunmuştur. Araştırmacıların farklı sınıflandırmalar yaptığı örnek türlerinde ise örneklerin konunun hangi kısmında ve hangi kazanım altında verildiği dikkate alınarak yeniden kodlama 
yapılmıştır. Örneğin, 9.4.3.1 kazanımında DK1'de yer alan bir örneğe ilişkin araştırmacılar farklı kodlamalar yapmıştır. "Bir kemençe ustası, kemençe yayını hareket ettirerek ona bir kinetik enerji kazandırır. Ustanın yayı kemençe tellerine sürtmesi sirasında (Görsel 4.3.2) ses açığa çıkar. Sürtünme nedeniyle kemençe telleri ve yay ısınır. Bu sırada enerjinin büyük çoğunluğu ses enerjisine dönüşür." örneği kinetik enerjinin tanıtımının hemen sonrasında verilen bir örnek olsaydı tanımın bir standart örneği olabilirdi. Ancak enerjinin bir biçimden diğer biçimine dönüşümünde toplam enerjinin korunduğunun vurgulandığı kazanıma giriş yapmak için dikkat çekici bir örnek olarak kullanılmıştır. Bu bakımdan her iki araştırmacı da ilgili örneğin başlangıç örnek türünü temsil ettiği konusunda hemfikir olmuşlardır. Kıyaslamada uyuşmayan diğer bütün kodlamalarda da benzer bir yol izlenmiştir.

Tablo 2

Enerji Ünitesine İlişkin Kazanımlar

\begin{tabular}{|c|c|}
\hline Kazanım No & Kazanım \\
\hline 9.4 .1 .1$. & İş, enerji ve güç kavramlarını birbirleriyle ilişkilendirir. \\
\hline 9.4.1.2. & Mekanik iş ve mekanik güç ile ilgili hesaplamalar yapar. \\
\hline 9.4.2.1. & $\begin{array}{l}\text { Öteleme kinetik enerjisi, yer çekimi potansiyel enerjisi ve esneklik potansiyel } \\
\text { enerjisinin bağll olduğu değişkenleri analiz eder. }\end{array}$ \\
\hline 9.4.3.1. & $\begin{array}{l}\text { Enerjinin bir biçimden diğer bir biçime (mekanik, 1s1, 1ş1k, ses gibi) dönüşümünde } \\
\text { toplam enerjinin korunduğu çıkarımını yapar. }\end{array}$ \\
\hline 9.4.3.2. & $\begin{array}{l}\text { Canlıların besinlerden kazandıkları enerji ile günlük aktiviteler için harcadıkları } \\
\text { enerjiyi karşılaştırır. }\end{array}$ \\
\hline 9.4.4.1. & Verim kavramını açıklar. \\
\hline 9.4.4.2. & Örnek bir sistem veya tasarımın verimini artıracak öneriler geliştirir. \\
\hline 9.4.5.1. & $\begin{array}{l}\text { Yenilenebilir ve yenilenemez enerji kaynaklarını avantaj ve dezavantajları açısından } \\
\text { değerlendirir. }\end{array}$ \\
\hline
\end{tabular}

\section{Bulgular}

Fizik ders kitaplarında kullanılan örneklere ilişkin sınıflandırmaların frekans değerleri iki ayrı tablo şeklinde sunulmuştur. Tablo 3'te DK1'e, Tablo 4'te ise DK2'ye ilişkin frekans değerleri yer almaktadır. Tablo 3'e göre DK1'de toplamda 65 örnek incelenmiştir. İncelenen bu örneklerin bazılarının birkaç örnek türünü ve bazılarının alt maddelerinde sunulan örneklerin farklı örnek türlerini içerdiği görülmüştür. Bu nedenle tabloda örnek türlerinin toplamı 88 olarak görülmektedir. Bu örneklerin 35'i başlangıç, 21'i standart, 24'ü geliştirici, 3'ü örnek dış1 ve 5'i karşıt örnek olarak sınıflandırılmıştır. Uç örnek olarak nitelendirilebilecek bir örneğe rastlanılmamıştır.

Örnek türleri kazanımlar bakımından değerlendirildiğinde her kazanıma ilişkin farklı sayı ve türde örneklere yer verildiği görülmektedir. Bazı kazanımlarda ise bazı örnek türlerine ise hiç yer verilmediği belirlenmiştir. Başlangıç örneklerinden 12'si B1, 15'i B2 ve 8'i B3 kodları altında yer almaktadır. Birinci ders kitabında 9.4.4.2 kazanımı dışında bütün kazanımlar için başlangıç örneklerine yer verilmiştir. Standart örneklerden 8'i S1 5'i S2 ve 8'i S3 kodları ile tanımlanmıştır. 9.4.4.3 ve 9.4.4.2 kazanımlarına ilişkin standart örneklere yer verilmemiştir. Geliştirici örneklerden 4'ünü G1, 2'sini G2 ve 18'ini G3 kodlu örnekler oluşturmaktadır. 9.4.3.2 ve 9.4.4.1 kazanımlarına ilişkin geliştirici örneklere yer verilmediği belirlenmiştir. Örnek dış1 örneklerden ikisinin ÖD1, 1'inin ise ÖD2 kodlu örneklerden oluştuğu belirlenmiştir. 9.4.1.1. ve 9.4.1.2. kazanımlarına ilişkin örneklerde örnek dışı örneklere yer verildiği belirlenmiştir. Karşıt örnek olarak kodlanan 5 örneğin ise 9.4.1.2., 9.4.3.1. ve 9.4.4.2 kazanımlarına ait olduğu belirlenmiştir. 
Tablo 3

DKI'de Yer Alan Örneklerin Sinıflandırılması

\begin{tabular}{|c|c|c|c|c|c|c|c|c|c|c|c|c|c|c|}
\hline \multirow{3}{*}{ Kazanım } & \multirow{3}{*}{$\begin{array}{l}\text { Örnek } \\
\text { Sayıs1 }\end{array}$} & \multicolumn{13}{|c|}{ Örnek Türleri } \\
\hline & & \multicolumn{3}{|c|}{ Başlangıç } & \multicolumn{3}{|c|}{ Standart } & \multicolumn{3}{|c|}{ Geliştirici } & \multirow{2}{*}{$\begin{array}{l}\text { Uç } \\
\text { U1 }\end{array}$} & \multicolumn{2}{|c|}{ Örnek D1ş1 } & \multirow{2}{*}{$\begin{array}{c}\text { Karş1t } \\
\text { K1 }\end{array}$} \\
\hline & & B1 & B2 & B3 & S1 & $\mathrm{S} 2$ & S3 & G1 & $\mathrm{G} 2$ & G3 & & ÖD1 & ÖD2 & \\
\hline 9.4 .1 .1 & 11 & 1 & - & - & 1 & 3 & 4 & & 1 & - & - & 1 & 1 & - \\
\hline 9.4.1.2. & 9 & - & 2 & 2 & - & - & 2 & 2 & - & 5 & - & 1 & - & 2 \\
\hline 9.4.2.1. & 15 & 3 & 5 & 1 & 2 & 1 & 1 & 2 & 1 & 2 & - & - & - & - \\
\hline 9.4.3.1. & 9 & 4 & 3 & 4 & 2 & - & 1 & - & - & 3 & - & - & - & 1 \\
\hline 9.4.3.2. & 3 & 2 & 2 & - & - & - & - & - & - & - & - & - & - & - \\
\hline 9.4.4.1. & 2 & 1 & - & - & & 1 & - & - & - & - & - & - & - & - \\
\hline 9.4.4.2. & 3 & - & - & - & - & - & - & - & - & 1 & - & - & - & 2 \\
\hline 9.4.5.1. & 13 & 1 & 3 & 1 & 3 & - & - & - & - & 7 & - & - & - & - \\
\hline Toplam & 65 & 12 & 15 & 8 & 8 & 5 & 8 & 4 & 2 & 18 & 0 & 2 & 1 & 5 \\
\hline Örnek Sayısı & & & 35 & & & 21 & & & 24 & & & & & \\
\hline
\end{tabular}

Tablo 4'e göre DK2'de toplamda 62 örnek incelenmiştir. İncelenen bu örneklerin bazılarının birkaç örnek türünü ve bazılarının alt maddelerinde sunulan örneklerin farklı örnek türlerini içerdiği görülmüştür. Bu nedenle tabloda örnek türlerinin toplamı 76 olarak görülmektedir. $\mathrm{Bu}$ örneklerin 27'si başlangıç, 9'u standart, 32'si geliştirici, 4'ü örnek dışı ve 4'ü karşıt örnek olarak sınıflandırılmıştır. Uç örnek olarak nitelendirilebilecek bir örneğe rastlanılmamıştır. Örnek türleri kazanımlar bakımından değerlendirildiğinde her kazanıma ilişkin farklı sayı ve türde örneklere yer verildiği, bazı kazanımlarda ise bazı örnek türlerine ise hiç yer verilmediği belirlenmiştir.

Tablo 4

DK2'de Yer Alan Örneklerin Sinıflandırılması

\begin{tabular}{|c|c|c|c|c|c|c|c|c|c|c|c|c|c|c|}
\hline \multirow{3}{*}{ Kazanım } & \multirow{3}{*}{$\begin{array}{l}\text { Örnek } \\
\text { Sayıs1 }\end{array}$} & \multicolumn{13}{|c|}{ Örnek Türleri } \\
\hline & & \multicolumn{3}{|c|}{ Başlangıç } & \multicolumn{3}{|c|}{ Standart } & \multicolumn{3}{|c|}{ Geliştirici } & \multirow{2}{*}{$\begin{array}{l}\text { Uç } \\
\text { U1 }\end{array}$} & \multicolumn{2}{|c|}{ Örnek Diş1 } & \multirow{2}{*}{$\frac{\text { Karş1t }}{\text { K1 }}$} \\
\hline & & B1 & B2 & B3 & S1 & $\mathrm{S} 2$ & S3 & G1 & $\mathrm{G} 2$ & G3 & & ÖD1 & ÖD2 & \\
\hline 9.4.1.1. & 9 & 2 & 1 & 1 & - & 1 & 1 & - & - & - & - & 3 & 1 & - \\
\hline 9.4.1.2. & 2 & - & - & - & - & - & - & - & - & 2 & - & - & - & - \\
\hline 9.4.2.1. & 10 & 2 & 4 & 3 & - & - & 3 & - & - & 4 & - & - & - & - \\
\hline 9.4.3.1. & 11 & 1 & 1 & 1 & 1 & - & - & 1 & - & 7 & - & - & - & 1 \\
\hline 9.4.3.2. & 5 & - & 1 & 2 & - & - & 2 & - & - & - & - & - & - & - \\
\hline 9.4.4.1. & 4 & 1 & 1 & 1 & - & - & - & - & - & 1 & - & - & - & - \\
\hline 9.4.4.2. & 3 & - & - & - & - & - & - & - & - & - & - & - & - & 3 \\
\hline 9.4.5.1. & 18 & 1 & 3 & 1 & 1 & - & - & 2 & - & 15 & - & - & - & - \\
\hline \multirow{2}{*}{$\begin{array}{l}\text { Toplam } \\
\text { Örnek Sayısı }\end{array}$} & 62 & 7 & 11 & 9 & 2 & 1 & 6 & 3 & 0 & 29 & \multirow[t]{2}{*}{0} & 3 & 1 & \multirow[t]{2}{*}{4} \\
\hline & & & 27 & & & 9 & & & 32 & & & & & \\
\hline
\end{tabular}

Başlangıç örneklerinden 7'si B1, 11'i B2 ve 9'u B3 kodları altında yer almaktadır. 9.4.1.2. ve 9.4.4.1. kazanımları dışında bütün kazanımlar için başlangıç örneklerine yer verilmiştir. Standart örneklerden 2'i S1, 1'i S2 ve 6's1 S3 kodları ile tanımlanmıştır. 9.4.1.2. ve 9.4.4.1. kazanımları dışında bütün kazanımlar için başlangıç örneklerine yer verilmiştir. Geliştirici örneklerden 3'ünü G1 ve 29'unu G3 kodlu örnekler oluşturmaktadır. 9.4.1.1., 9.4.3.2., 9.4.4.1. ve 9.4.4.2. kazanımlarına ilişkin geliştirici örneklere yer verilmediği belirlenmiştir. Örnek dış1 örneklerden 3'ünün ÖD1, 1'inin ise ÖD2 kodlu örneklerden oluştuğu belirlenmiştir. Sadece 9.4.1.1. kazanımına ilişkin örneklerde örnek dışı örneklere yer verildiği belirlenmiştir. Karşıt örnek olarak kodlanan 4 örneğin ise 9.4.3.1. ve 9.4.5.1. kazanımlarına ait olduğu belirlenmiştir. Her iki kitapta kullanılan başlangıç örneklerine ilişkin alıntılar, örneklerin bulundukları sayfa numaraları ve kitaplarda enerji ünitesinde yer alan toplam başlangıç örnek sayıları Tablo 5 'te verilmiştir. Tablo 5'e göre DK1'de kullanılan başlangıç örneği sayısı 35, DK2'de kullanılan 
başlangıç örneği sayısı ise 27'dir. DK1'de yer alan örnek, yer çekimi potansiyel enerjisini tanımlamak, bu kavrama giriş yapmak için alt yapı oluşturmaya çalışan bir dizi başlangıç örneğini içermektedir. DK2'de yer alan başlangıç örneğinde ise kütle çekim potansiyel enerjisi kavramını tanımlamak için alt yapı oluşturma ve kavramı iş kavramı ile ilişkilendirme yer almaktadır.

Tablo 5

Fizik Ders Kitaplarında Kullanılan Başlangıç Örneklerinden Alıntılar

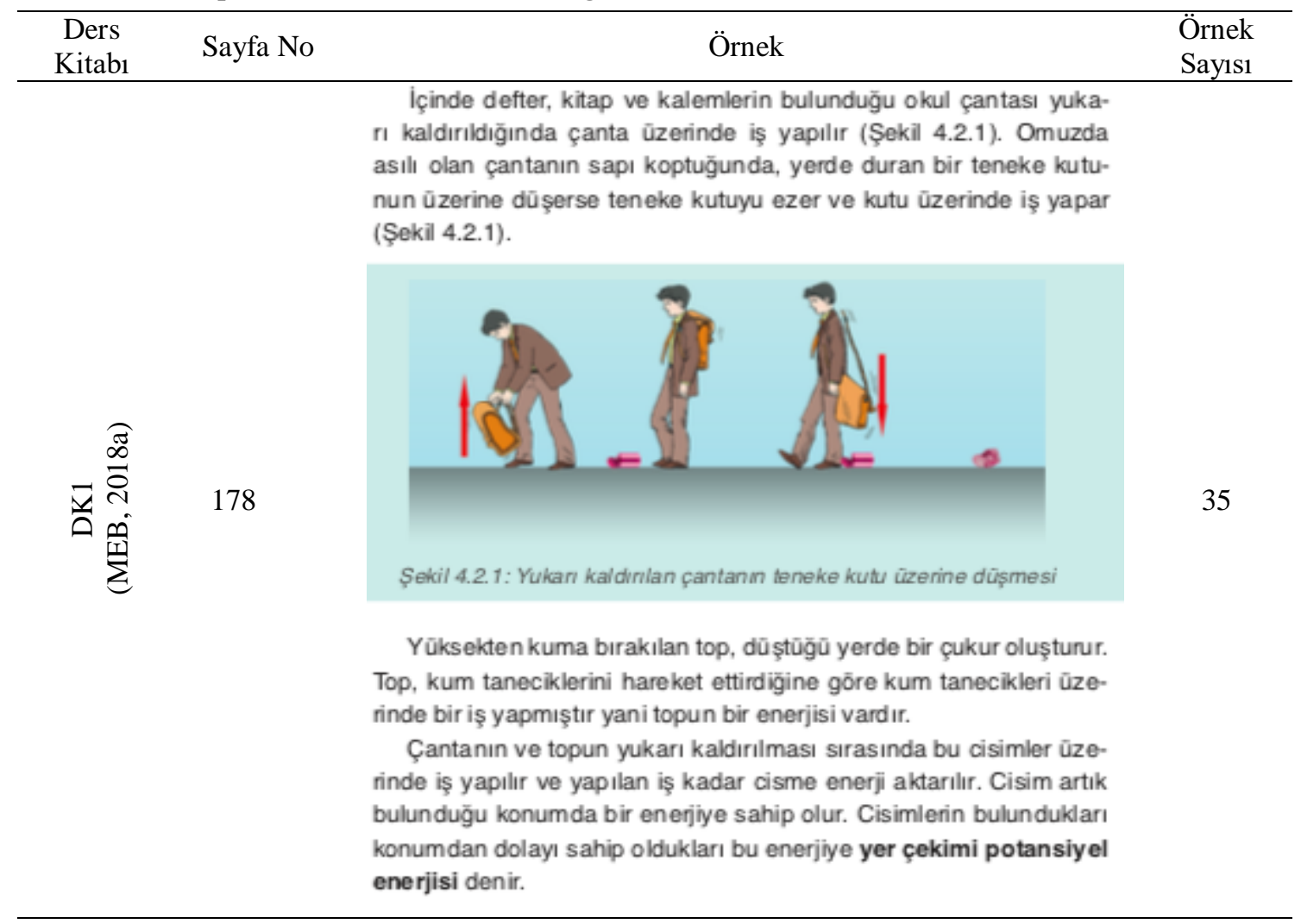

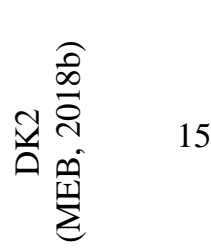

Dünya ve Dünya'daki cisimler de birbirine kuvvet uygulayan sistem olarak potansiyel enerjiye sahiptir. Örneğin Görsel 4.11'de yerden belirli bir yükseklikten atlayan paraşütçü için kütle çekim kuvveti (ağırlık) yere kadar yol boyunca iş yapar. Ağırlığın bu yolda yaptığ 1 iş miktarı kişinin ilk konumunda iken yere göre sahip olduğu enerji miktarı kadar olmalıdır. $\mathrm{Bu}$ enerjiye kütle çekim potansiyel enerjisi denir.

Her iki kitapta yer alan standart örneklere ilişkin alıntılar, örneklerin bulundukları sayfa numaraları ve kitaplarda enerji ünitesinde yer alan toplam standart örnek sayılarına ait bilgiler aşağıdaki Tablo 6'da verilmiştir. Tablo 6'ya göre DK1'de kullanılan standart örnek sayısı 21, DK2'de kullanılan standart örnek sayıs1 ise 9'dur. DK1'de yer alan örnek, iş yapabilme koşulları içerisinde yer alan 'kuvvet uygulanan cismin kuvvet doğrultusunda yer değiştirmesi gerekir' kuralını yansıtmak için verilmiş bir standart örnektir. DK2'de yer alan örnekte ise bir cismin üzerinde yapılan işin hesaplanması sürecinin nasıl gerçekleştiğini gösteren bir standart örneğe yer verilmiştir. 
Tablo 6

Fizik Ders Kitaplarında Kullanılan Standart Örneklerinden Alıntılar

\begin{tabular}{cccc}
$\begin{array}{c}\text { Ders } \\
\text { Kitabi }\end{array}$ & $\begin{array}{c}\text { Sayfa } \\
\text { No }\end{array}$ & Örnek & $\begin{array}{c}\text { Örnek } \\
\text { Sayısı }\end{array}$ \\
\hline & & $\begin{array}{c}\text { Örneğin, Şekil 4.1.1'deki gibi masaya bir F kuvveti uygulandığında } \\
\text { masa hareket ederse kuvvet, masa üzerinde iş yapmış olur. }\end{array}$ \\
& & &
\end{tabular}

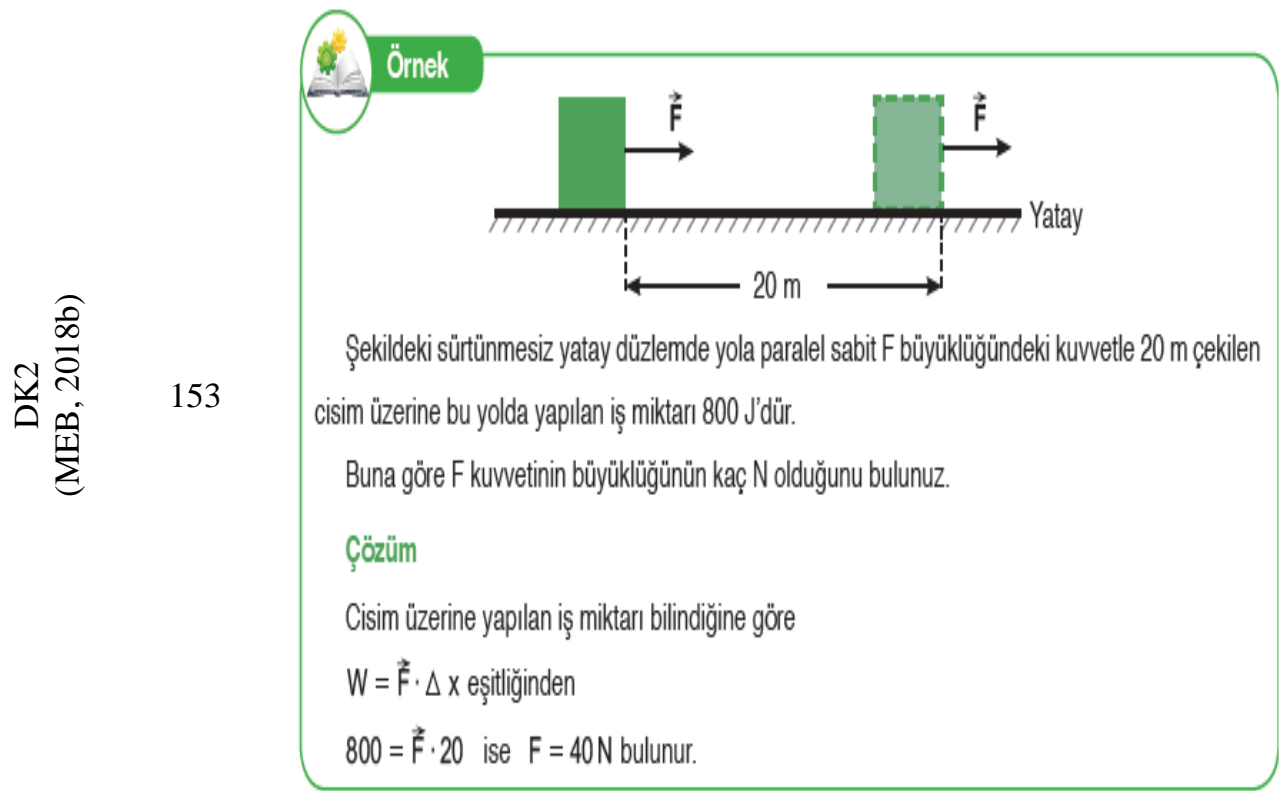

Her iki kitapta kullanılan geliştirici örneklere ilişkin alıntılar, örneklerin bulundukları sayfa numaraları ve kitaplarda enerji ünitesinde yer alan toplam geliştirici örnek sayıları Tablo 7'de yer almaktadır. Tablo 7'ye göre DK1'de kullanılan geliştirici örnek sayıs1 24, DK2'de kullanılan geliştirici örnek sayısı ise 32'dir. DK1'de yer alan örneğin 'a' seçeneğinde iş hesaplaması yaparken birim çevirmeye de yer vermiştir. Öğrencilerde 'birim her zaman metre olarak verilir' şeklinde oluşabilecek bir algıyı geliştirmeye yönelik bir geliştirici örnek olarak değerlendirilmiştir. DK2'de yer alan örnekte ise iş hesaplama sürecinde kuvvet olarak sürtünme kuvveti de eklenmiştir. 'Bir cisme birden fazla kuvvet etki ettiğinde' cismin üzerine yapılan net iş hesabının nasıl gerçekleştirileceğini gösteren geliştirici bir örnektir. 
Tablo 7

Fizik Ders Kitaplarında Kullanılan Gelişstirici Örneklerinden Alıntılar

\begin{tabular}{|c|c|c|c|c|}
\hline $\begin{array}{c}\text { Ders } \\
\text { Kitab1 } \\
\end{array}$ & $\begin{array}{c}\text { Sayfa } \\
\text { No }\end{array}$ & \multicolumn{2}{|c|}{ Örnek } & $\begin{array}{l}\text { Örnek } \\
\text { Sayı1s1 }\end{array}$ \\
\hline 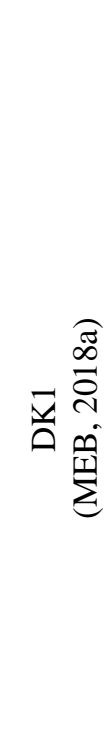 & 171 & $\begin{array}{l}\text { ÖRNE SORU } \\
\text { Oyuncak araba sürtünme kuvvetinin sabit ve } 4 \\
\mathrm{~N} \text { șiddetinde olduğu masa üzerinde şekildeki } \\
\text { gibi yatay yola paralel } 20 \mathrm{Nllik} \text { kuwetin etkisi } \\
\text { altında } 70 \mathrm{~cm} \text { yer değiștiriyor. } \\
\text { Buna göre; } \\
\text { a) } 20 \mathrm{~N} \text { 'lik kuvvetin, } \\
\text { b) Sürtünme kuvvetinin, } \\
\text { c) Net kuvvetin yaptığı iș kaç J'dür? }\end{array}$ & 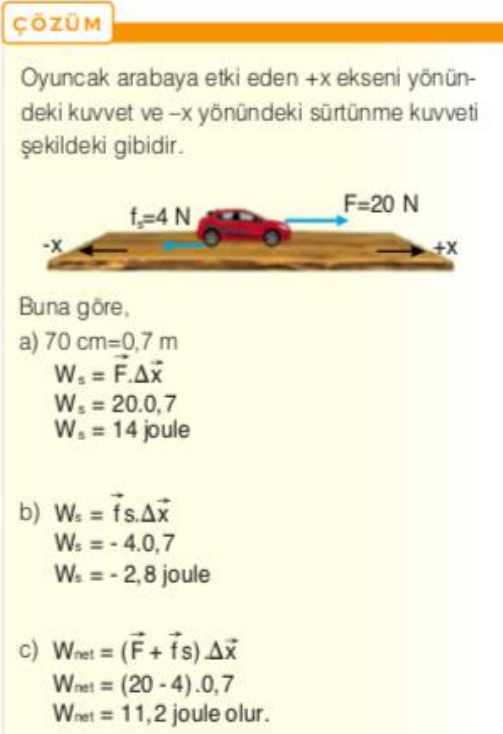 & 24 \\
\hline 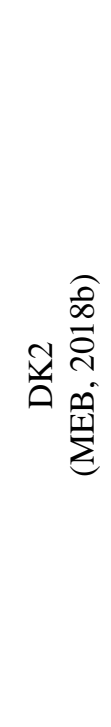 & 154 & $\begin{array}{l}\text { Şekildeki } 2 \mathrm{~kg} \text { kütleli cisim, yola paralel } 18 \mathrm{~N} \text { 'lı } \\
\text { Cisme etkiyen sürtünme kuvveti } 10 \mathrm{~N} \text { olduğun } \\
\text { rının kaç J olduğunu bulunuz. } \\
\text { Çözüm } \\
\text { Bu durumda cisme etkiyen } 18 \text { N'lık kuvvet, poz } \\
\text { sürtünme kuvveti aynı yolda negatif iş yapacaktır. } \\
\text { Net iş miktarı, } \\
W_{\text {net }}=\left(\mathrm{F}-\mathrm{F}_{\mathrm{s}}\right) \cdot \Delta \mathrm{x} \\
\mathrm{W}_{\text {net }}=(18-10) \cdot 8 \\
\mathrm{~W}_{\text {net }}=8 \cdot 8 \\
\mathrm{~W}_{\text {net }}=64 \mathrm{~J} \text { bulunur. }\end{array}$ & 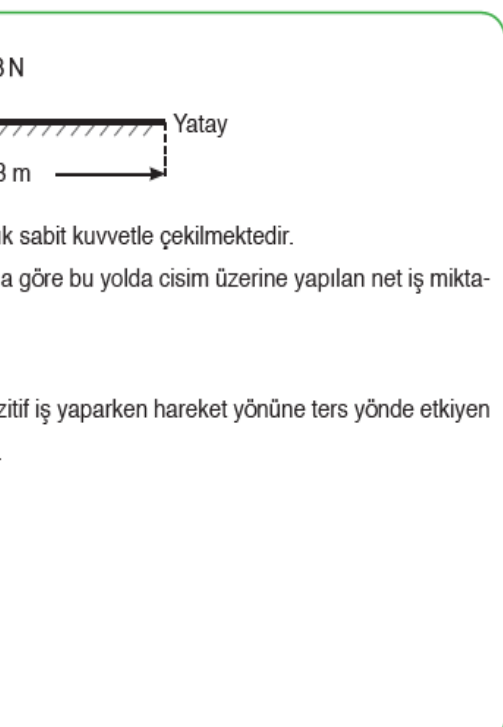 & 30 \\
\hline
\end{tabular}

Her iki kitapta kullanılan örnek dışı örneklere ilişkin alıntılar, örneklerin bulundukları sayfa numaraları ve kitaplarda enerji ünitesinde yer alan toplam örnek dışı örnek sayıları Tablo 8'de yer almaktadır. Tablo 8'e göre DK1'de kullanılan örnek dışı örnek sayısı 3, DK2'de kullanılan örnek dişı örnek sayısı ise 4'tür. DK1'de yer alan iş yapabilme koşulları içerisinde yer alan 'kuvvet uygulanan cismin kuvvet doğrultusunda yer değiştirmesi gerekir' kuralını sağlamayan bir örnek dış1 örneğe yer verilmiştir. DK2'de yer alan örnekte de benzer şekilde iş yapma koşullarına uymayan bir durumu anlatmak için örnek dışı örneğe yer verilmiştir. 
Tablo 8

Fizik Ders Kitaplarında Kullanılan Örnek Dışı Örneklerinden Alıntılar

\begin{tabular}{|c|c|c|c|}
\hline $\begin{array}{c}\text { Ders } \\
\text { Kitab1 }\end{array}$ & Sayfa No & Örnek & $\begin{array}{l}\text { Örnek } \\
\text { Sayı1s1 }\end{array}$ \\
\hline \multirow{3}{*}{ 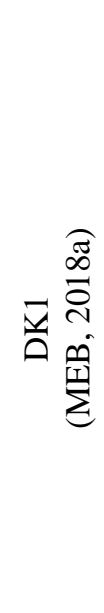 } & & $\begin{array}{l}\text { Omuza yerleştirilen bir kutuyla düz bir zeminde yürürken iş } \\
\text { yapılmaz (Görsel 4.1.2). Çünkü kuvvet yukarı yönde, yer } \\
\text { değiștirme ise yatay düzlemde ileri yöndedir. Kuvvet ve yer }\end{array}$ & \multirow{3}{*}{3} \\
\hline & 165 & & \\
\hline & & Görsel 4.1.2: Omuzda yük tașıma & \\
\hline
\end{tabular}

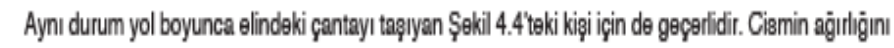

dengelemek için uygulanan $F{ }^{*}$ kuvveti $\Delta x$ yolunu aldiran kuwvt olmadigindan ią yapmaz.

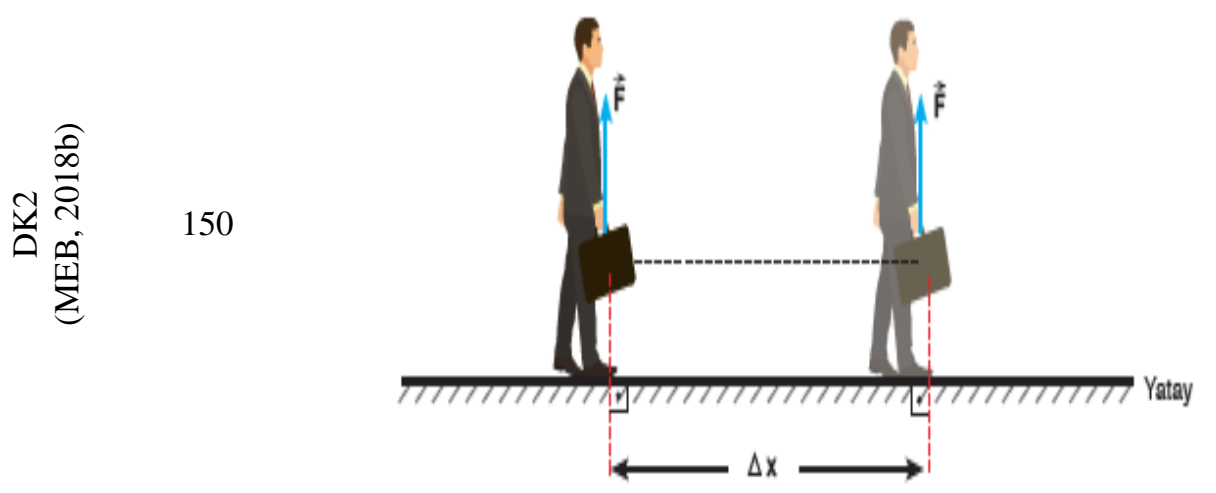

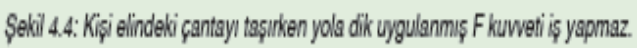

Örnek olması bakımından her iki kitapta kullanılan karşıt örneklere ilişkin alıntılar, örneklerin bulundukları sayfa numaraları ve kitaplarda enerji ünitesinde yer alan toplam karşıt örnek sayılarına ait bilgiler Tablo 9'da yer almaktadır. Tablo 9'a göre DK1'de kullanılan karşıt örnek sayıs1 5, DK2'de kullanılan geliştirici örnek sayıs1 ise 4'tür. DK1'de yer alan örnek öğrencilerin 'yapılan işin her zaman pozitif olabileceğine' ilişkin yanlış genellemelere ulaşmalarını engellemede kullanılmış bir karşıt örnektir. DK2'de yer alan örnekte ise 'enerjinin tamamının istenilen işe dönüştürülebileceği' genellemesine ulaşmalarını engellemede kullanılmış bir karşıt örnektir. 
Tablo 9

Fizik Ders Kitaplarında Kullanılan Karşıt Örneklerinden Alıntılar

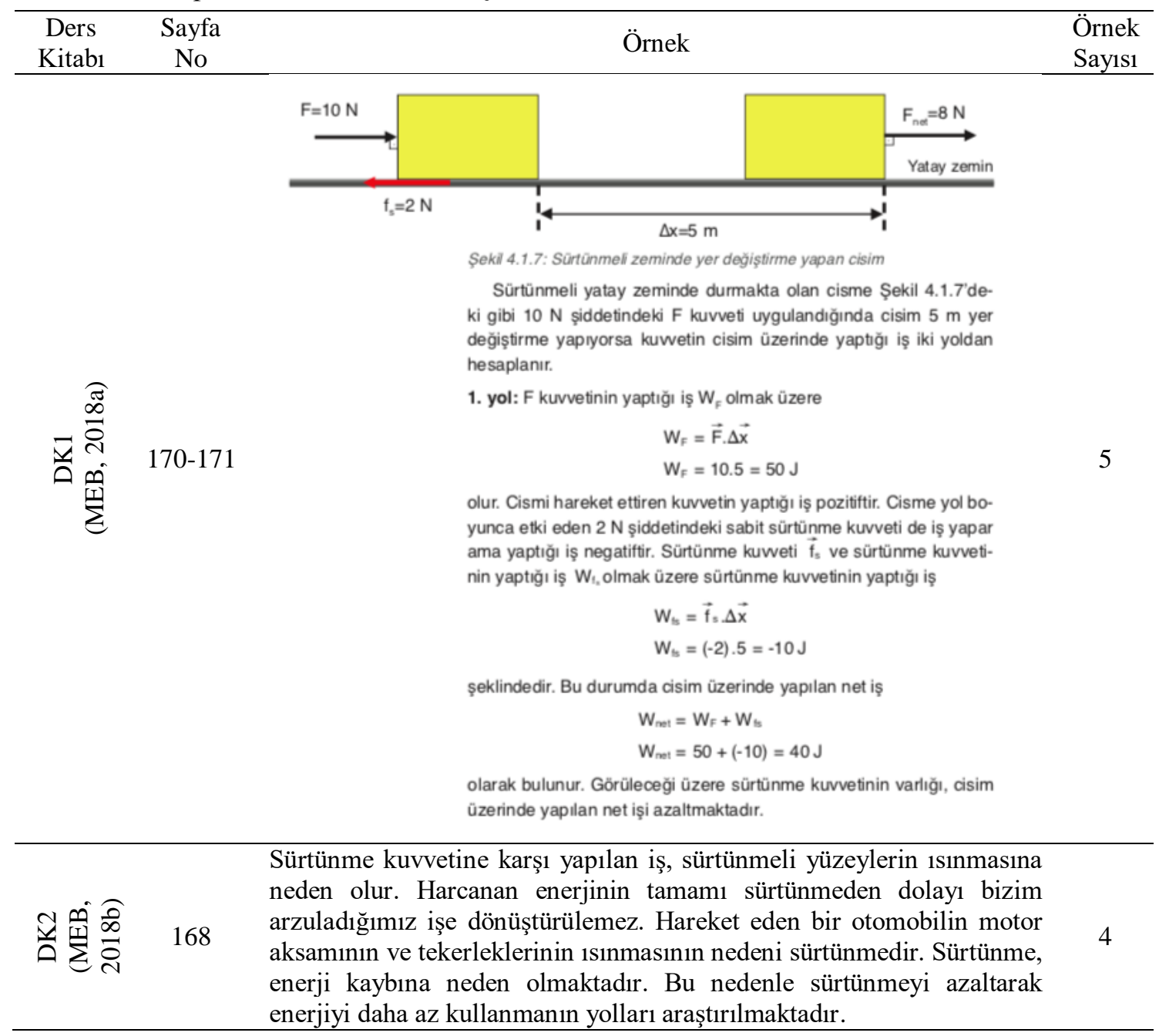

\section{Tartışma, Sonuç ve Öneriler}

Ders kitaplarında kullanılan örnekler enerji ünitesindeki tüm kazanımlar için tek tek tartışılmış ve sonuçlandırılmıştır. 9.4.1.1. kazanımı; enerji ünitesine giriş yapılan, ünite ile ilgili temel kavramların bulunduğu iş, güç ve enerji kavramlarının tanıtıldığı bir kazanımdır. Öğrencilerin bu kazanım doğrultusunda iş, güç ve enerji kavramlarının günlük hayattaki yerleri ile ilgili temel bilgilere sahip olmaları istenmektedir (MEB, 2018). Öğretim programının amaçları incelendiğinde öğrencilerin 9. ve 10. sinıfta matematiksel işlemlerden ziyade, çevresinde gördüğü olayları fizik kuralları doğrultusunda açıklayarak, fizik dersinin yaşamın bir parçası olduğunu görmeleri beklenmektedir (MEB, 2018). Bu beklenti doğrultusunda kullanılan örneklerin kavramla ilgili günlük yaşamdan kesitler içermesi gerekmektedir. Dolayısıyla ders kitaplarında bu anlamda başlangıç örneklerine yer verilmesinin ve sayısının yeterli düzeyde olmasının öğretim programındaki beklentiyi daha iyi karşılayacağ düşünülmektedir. Kitaplar bu düşünce doğrultusunda incelendiğinde; DK1 beklentiyi karşılayamamıştır ancak bu kazanıma ait ders kitabında örnek dışı örneklerin yer aldığı görülmüştür. Bu örnek türünün kullanım amacı göz önüne alındığında; iş kavramının, 'iş olmayan durumların betimlenmesi' ile açıklanması buradaki başlangıç örnek sayısının az olmasından kaynaklanan eksikliği kapatabileceği düşünülmüştür. Alkan (2016), örnek dışı örneklerin kullanım yeri ile ilgili bir sınırlama olmadığını, bu tip örneklerin konunun başında da kullanılabileceğini ifade etmiştir. 
9.4.1.1. kazanımında belirli kavramların tanımlarına yer verildiği için standart örnek sayısının diğer örnek türlerinin sayısından fazla olması beklenilmektedir. Öğretim programında da öğrencilerin bu kavramların tanımları hakkında bilgi sahibi olmaları gerektiği belirtilmektedir. (MEB, 2018). DK2 bu kazanımda kullanılan örnek türleri açısından değerlendirildiğinde, başlangıç örnek sayısının DK1'den daha fazla olduğu ve örnek dış1 örneklere DK2'de daha fazla yer verildiği görülmüştür. Bu durum kavramlara ilişkin özelliklere öğrencilerin dikkatini çekerek onların kavramlara odaklanmalarına yardımcı olabilir. Verilen standart örneklerin sayısının daha az olması ise kavramların tanımlarını ders kitabından öğrenen bir öğrencinin tanımları ve bu tanımlara ilişkin yürütülen matematiksel süreçlerin nasıl uygulandığını yeteri kadar anlamlı hale getirememelerine sebep olabilir.

9.4.1.2. kazanımı ile 9.4.1.1. kazanımda başlangıç ve tanımlara ait standart örnekleri inceleyen öğrencilerden geliştirici örnekler aracılığıyla tanıma ilişkin algılarını genişletmeleri beklenilmektedir. Bu duruma bağlı olarak ders kitaplarında geliştirici örnek türlerinin daha fazla kullanılması uygun görülmektedir. Bu bağlamda ders kitapları incelendiğinde geliştirici örnek sayısının DK1'de daha fazla olması, bu ders kitabı ile öğrenim gören öğrencilerin kavramla ilgili daha fazla örnekle karşılaşmalarına ve ifade edilen kavramları diğer kavramlarla daha rahat ilişkilendirebileceklerine işaret etmektedir. DK2'de bu kazanıma ilişkin sadece iki geliştirici örnek yer almaktadır. Bu bakımdan DK1'de bu örnek türünün daha fazla olması hem öğrenciler hem de öğretmenler açısından yararlı olacağı düşünülmektedir. Geliştirici örnekler 9. sınıfta başlangıç ve standart örnekler aracılığıyla öğrenilen kavramlara ilişkin hem bir derinleştirme hem de ileriki seviyeler için hazır bulunuşluk sağlayacaktır. Enerji ünitesinin 11. sınıf fizik ögretim programında yer alması bakımından öğrencilerin bu konuda hazır bulunuşluklarının yeterli düzeyde olması beklenmektedir. Hazır bulunuşluğu olmayan öğrencilere bu kavramları ayrıntılı bir biçimde tekrar hatırlatmak öğretmenin öğretim programındaki kazanımlarını planlanan zamanda gerçekleştirmesi bakımından bir engel olarak karşısına çıkabilir. Geliştirici örnek türü öğrencilerin muhakeme yeteneklerini geliştirip 11.sınıf enerji konusu için iyi bir ön öğrenme sağlayabilir. Ayrıca DK1'de kazanıma ilişkin karşıt örneklerin de yer aldığı görülmektedir. DK1'de sürtünme kuvvetinin yaptığı işin negatif olduğunu vurgulamak için ayrı bir karşıt örneğe yer verilmiştir. DK2'de ise bu tür bir örnek ayrı bir örnekte verilmeden başka geliştirici örneğin içerisine yerleştirilmiştir. Sürtünme kuvvetin yaptığı işin negatif olarak vurgulanması öğrencilerde oluşabilecek muhtemel kavram yanılgılarının önüne geçmede önemli bir yere sahiptir. Bununla birlikte 9.4.3.1 kazanımında vurgulanan enerji dönüşümlerinde sürtünme kuvvetinin yaptı̆̆ 1 işin öneminin anlaşılmasında verilen karşıt örnekler önemli bir yer tutmaktadır. Özellikle kavramlar arası ilişkileri vurgulamak amacıyla kullanılan geliştirici örnekler öğrenenleri kavramlarla ilgili aşırı genellemeler yapmalarına ve kavramlarla ilgili yanılgılara sahip olmalarına neden olabilir. Bu bağlamda karşı örneklerin ders kitaplarında yer alması öğrenenlerin kavram bilgisinin daha sağlıklı oluşmasını sağlar (Alkan ve Güven, 2018).

9.4.2.1. kazanımı ile enerjinin tanımı yapıldıktan sonra enerji türlerinin kavramsal düzeyde verildiği bir kazanıma geçiş yapılmıştır. Öğrencilerin burada belirtilen enerji türlerinin hangi değişkenlere bağlı olduğunu matematiksel işlemlere girmeden analiz etmeleri beklenmektedir (MEB, 2018). Enerji kavramı içerisinde alt başlıklar açan bu kazanımda öğrencilerin bu kavramlara dikkatinin çekilmesi için başlangıç örneklerinin, bu kavramlara ilişkin değişkenlerin analizi için standart örneklerin ve bu kavramların diğer kavramlarla ilişkilendirilebilmesi amacıyla geliştirici örneklerin (başlangıç, standart ve geliştirici şeklinde) uygun sırada kullanılması gerekmektedir (Alkan, 2016). Özellikle bu kazanımın 11. sınıf fizik öğretim programındaki kinetik, yer çekimi potansiyel ve esneklik potansiyel enerjisi kavramlarının alt yapısının 9. sınıfta bu kazanımla birlikte öğrencilere kazandırılmaya çalışılmaktadır. Bu nedenle bu kavramların öğrencilerin zihninde sağlıklı bir şekilde yapılandırılması önemlidir. Aynı zamanda 12. sınıfta dönme kinetik enerjisi kavramının da bu kavramlar üzerinden inşa edileceği göz önünde bulundurulduğunda bu kavramların temel teşkil ettiği ortaya çıkmaktadır. $\mathrm{Bu}$ 
bakımdan bu kavramlara ilişkin verilen örneklerin yeterli sayıda, uygun dağılımda ve nitelikte verilmesi önemli görülmektedir. DK1'de verilen örnek sayılarının ve dağılımının bu açıdan DK2'de verilen örnek sayısı ve dağılımından daha uygun olduğu ifade edilebilir. DK1'de kullanılan başlangıç, standart ve geliştirici örnek türlerinin DK2'de kullanılan örnek sayısından daha fazla olmasının yanı sıra bu örneklerin kullanım amaçları da dikkate alındığında DK1'de kavramsal içerikli örnek sayısının daha fazla olduğu ifade edilebilir.

9.4.3.1. kazanımı ile enerji dönüşümüne ilişkin örneklerde sürtünmeden dolayı harcanan enerjiye dikkat edilmesi ve matematiksel hesaplamalara girilmeden enerji dönüşümünden bahsedilmesi gerekmektedir. Bu aşamada enerji dönüşümü ile ilgili dikkat çekici örneklerin, prosedürün nasıl uygulanacağının ve bu örneklerin günlük hayatımızla nasıl ilişkilendirilebileceğinin vurgulanması önemlidir. Bu bakımdan başlangıç, standart ve geliştirici örneklerin sunulmasının uygun olacağı düşünülmektedir. Toplam örnek sayısı bakımından kitaplar incelendiğinde DK2'deki örnek sayısının daha fazla olduğu görülmektedir. Her iki kitapta da karşıt örnek türünden 1 tane yer almaktadır. Enerji problemlerinde ortamın sürtünmeli ya da sürtünmesiz olarak vurgulanması problemin çözümüne ilişkin farklı prosedürlerin uygulanmasını gerektirmektedir. Öğrenciler prosedürleri birbirine karıştırdığı takdirde yanlış bir çözüm yoluna gireceklerdir. Kitaplardaki karşıt örnekler 'yapılan işin tamamının hedeflenen enerjiye' dönüşebileceği olası yanılgısını engellemek amacıyla sürtünme kuvvetinin varlığına dikkat çeken örneklerdir. Liu ve Fang (2016), bu tür yanılgıların, öğrencileri sürtünmesiz ve sürtünmeli durumları içeren problem çözme aktivitelerine maruz bırakarak düzeltilebileceğini öne sürmekte, böylece öğrencilerin eleştirel düşünme ve muhakeme becerileri geliştirebileceklerini ve anahtar kavramlarda tam bir ustalık kazanabileceklerini ifade etmektedirler. Bu bakımdan her iki kitapta da verilen karşıt örnek sayılarının arttırılması uygun olabilir.

9.4.3.2. kazanımı ile bazal metabolizma hızı kavramının tanımının önemli bir yer tuttuğu bu kazanımda öğrencilerin besinlerle kazanılan ve aktivitelerle harcanan enerjileri karşılaştırmaları beklenmektedir (MEB, 2018). Buna göre ders kitaplarında bazal metabolizma kavramının tanımının yapılması açısından başlangıç ve standart örnek türlerine yer verilmesinin uygun olduğu düşünülmektedir. Başlangıç ve standart örnekler açısından incelendiğinde DK2'de yer alan örnek sayısının daha fazla olduğunu gözlemlemek mümkündür. Her iki ders kitabında da yer alan başlangıç ve standart örneklerin kalori değerleri verilmiş besin ve aktiviteleri dikkate aldığı görülmüştür. Bunların yanı sıra bu kazanıma dair geliştirici örneklere yer verilmemesi dikkat çekici bir durumdur çünkü günümüzde 'obezite' hastalığı her yaştan insanın karşısına bir problem olarak çıkmaktadır (Adıyaman, 2016). Geliştirici örneklerin kullanım amacı göz önünde bulundurulduğunda öğrencilerin kazanımla ilgili alışılmış standart örneklerin dışında canlıların besinlerden kazandığı enerjiler için daha geniş daha kapsamlı örneklerin yer almasının yararlı olacağı düşünülmektedir. $\mathrm{Bu}$ bakımdan paketlenmiş yiyecek ve içeceklerin kalori hesabının da yapılması öğrencilerin yeme-içme alışkanlıklarına ilişkin algılarının geliştirilmesinde ve enerji kavramının günlük hayatla ilişkilendirilmesinde önemlidir. Öğretim programlarının başarısında ders kitaplarının önemli bir rol oynadığı kabul edildiğinde ders kitaplarının disiplinler arası yaklaşıma göre hazırlanması gerekmektedir (Arslan ve Özpınar, 2009; Karakuş, Türkkan ve Karakuş, 2017). Bu bakımdan geliştirici örneklerin eklenmesi uygun görülmektedir.

9.4.4.1. kazanımı ile enerji tasarrufu ve verimliliği arasındaki ilişkinin enerji kimlik belgeleri üzerinden açıklanmasının beklenildiği (MEB, 2018) bu kazanıma ilişsin DK1'de başlangıç örneklerine yer verilmiştir. Verilen başlangıç örneklerinde enerji kimlik belgelerine ait bir görselin olmaması günlük hayatla ilişkilendirme boyutunun eksik kaldığını göstermektedir. DK2'de ise örnekler verilirken enerji kimlik belgesinden yararlanılmıştır ve sadece bir tane geliştirici örneğe yer verilmiştir. Enerjinin günümüz sorunlarından en önemlisi olduğu (Adıyaman, 2012), enerji tasarrufu ve verimliliği hakkında öğrencilerimizin farkındalık 
kazanması gerektiği bir durumda bu konuya ilişkin farklı disiplinlerle ve gündelik hayatla ilişkilendiren geliştirici örnek sayısının arttırılması gerektiği düşünülmektedir.

9.4.4.2. kazanımı ile çeşitli verim arttıcı sistemlerin tasarlanması tarihsel süreç içerisinde incelenmesi gerektiği belirtilmiş̧ir. Her iki kitapta da enerji kaybı olmadan çalışması düşünülen makinelerin tarihsel gelişimi incelenmiştir. Buna bağlı olarak ders kitaplarında karşıt örnekler aracılığıyla bu kazanımı açıklamaya çalışıldığı görülmüştür. Bu durumda bu tür mükemmel motor tasarımlarının termodinamik yasalarına göre henüz mümkün olmadığını karşıt örneklerle anlatılmasının uygun olduğu görülmüştür.

9.4.5.1. kazanımı ile yenilenebilir ve yenilenemez enerji kaynaklarına dikkat çekme, tanımları için alt yapı oluşturma amacıyla her iki kitapta da başlangıç ve standart örneklere yer verilmiştir. Enerji kaynaklarının maliyeti, ulaşılabilirliği, üretim kolaylığı, toplum, teknoloji ve çevre üzerine etkileri ve tasarruflu kullanımlarının vurgulandığ sayısının DK2'de daha fazla olduğu görülmüsstür. Tortop (2012) öğrencilerin yenilenebilir enerji kaynakları hakkında yaptığı çalışmasında öğrencilerin yenilenebilir enerji kaynakları hakkındaki farkındalıklarının ve bilgi düzeylerinin çok düşük seviyede olduğu sonucuna ulaşmıştır. Çakırlar (2015) öğrencilerin yenilenebilir enerji kaynakları konusunda farkındalık düzeylerini belirlemeyi amaçlamıştır. Çalışmanın sonuçlarından biri 9. sınıfta ögrenim gören öğrencilerin farkındalık düzeylerinin diğer sınıf düzeylerinden daha düşük olmasıdır. Çakırlar (2015), bu sonucun yenilenebilir enerji kaynaklarına ilişkin bilgilerin ortaöğretim 9. sınıf fizik ve biyoloji ders kitaplarında daha az ele alınması olabileceğini ifade etmiştir. Öğrencilerin alternatif enerji kaynakları hakkında farkındalıklarının arttırılması adına bu kaynaklarla ilgili DK1'de daha fazla örneğe yer verilmesi gerektiği uygun görülmektedir. Adıyaman (2012) Türkiye'nin yenilenebilir enerji politikaları adlı tez çalışmasında enerji üretiminde enerji kaynağı olarak alışıldık yöntemlerden (fosil kökenli yakıtlar olan kömür, petrol ve doğalgaz ağırlıklı) yararlanıldığının fakat bu yöntemlerin dünyanın doğal dengesini bozmaya başladığını bunun için farklı çevreye zarar vermeyen yenilenebilir enerji çeşitlerinin kullanımının arttırılmasını ifade etmiştir. Dünyamızın geleceği için son derece önemli olan bu konuda, öğrencilerin ders kitaplarında farklı enerji çeşitlerine ait bilgilerinin geliştirilmesi ve buna yönelik örneklerin ders kitaplarında daha fazla yer verilmesi gerekmektedir.

$\mathrm{Bu}$ çalışmadan elde edilen sonuçlar sadece bir ünite de belirtilen örneklere göre bulunmuştur. Kitaplarda yer alan diğer ünitelerdeki örnekler de ilgili kazanımların amaçları doğrultusunda incelenebilir. Farklı düzeylerde MEB tarafindan okutulan kaynaklarda yer alan örenekler incelenerek bu tür çalışmalar yapılabilir ve sonuçları kıyaslanabilir. Örneklerin sınıflandırılmasının yanı sıra ders kitaplarında kullanılan örneklerin öğrencilerin kavramsal anlamaları üzerine etkisi de araştırılabilir. Ders kitaplarında kullanılan örneklerin türlerinin tespit edilip kazanımların amacına uygun olup olmadığı araştırılabilir ve araştırma sonuçları doğrultusunda ders kitaplarında gerekli ise bu yönde iyileştirmeler yapılabilir. Bütün bu sonuçlar ışığında ders kitaplarının enerji ünitesi düzenlenirken olası kavram yanılgılarının önüne geçilmesi bakımından örnek dışı örnek ve karşıt örneklere daha fazla yer verilmesi, disiplinler arası ve günlük hayattan örnekler kullanılmasına dikkat edilmesi, kullanılan örnek sayıs1, dağılımı ve örneklerin niteliklerine önem gösterilmesi gerekmektedir.

\section{Etik Kurul Onay Bilgileri}

$\mathrm{Bu}$ araştırmada kullanılan veriler doküman incelemesi yoluyla elde edilmiştir. $\mathrm{Bu}$ nedenle araştırma, etik kurul kararından muaftır.

Çıkar Çatıșması

Yazarlar, bu çalışma kapsamında herhangi bir çıkar çatışmasının olmadığını beyan etmiş̧lerdir. 


\section{Finansal Destek}

Yazarlar, bu çalışma için herhangi bir finansal destek almadıklarını beyan etmişlerdir.

\section{Kaynaklar}

Adıbelli, S. (2007). Yeni programa göre hazırlanan lise 1 fizik ders kitabının eğitsel, görsel, dil ve anlatım yönünden incelenmesi (Yüksek lisans tezi). Selçuk Üniversitesi, Fen Bilimleri Enstitüsü, Konya. http://acikerisimarsiv.selcuk.edu.tr:8080/xmlui/bitstream/handle/ 123456789/9433/212346. pdf?sequence $=1 \&$ isAllowed $=y$ adresinden erişilmiştir.

Adıyaman, Ç. (2012). Türkiye'nin yenilenebilir enerji kaynakları (Yüksek lisans tezi). Niğde Üniversitesi, Sosyal Bilimler Enstitüsü, Niğde. http://acikerisim. nigde.edu.tr/xmlui/ handle/11480/431\#sthash.DqFxH7PD.dpbs adresinden erişilmiştir.

Adıyaman, F. (2016). Dünya sağlık örgütü avrupa obezite ile mücadele bakanlar konferansının öncesi ve sonrasında obezitenin gazetelerde sunumu. Selçuk Üniversitesi İletişim Fakültesi Akademik Dergisi 9(3), 204-223. doi: 10.18094/si.77372

Aktamış, H., Feyzioğlu, B., Özenoğlu Kiremit, H. ve Delioğlu, Y. (2010, Eylül). 9. sinıf fizik ögretim programına göre hazırlanan ders kitabının deney türleri ve bilimsel süreç becerileri açısından değerlendirilmesi. IX. Ulusal Fen Bilimleri Matematik Eğitimi Kongresinde (UFBMEK) sunulan bildiri, İzmir- Türkiye.

Alkan, S. (2016). Matematik öğretmenlerinin kullandıkları örneklerin sinıflandırılması ve ögretimsel açıklama boyutlartyla ilişkisinin incelenmesi (Doktora tezi). https://tez.yok.gov.tr/UlusalTezMerkezi/ adresinden erişilmiştir (Tez No: 448314).

Alkan, S. ve Güven, B. (2018). Ders kitaplarında kullanılan örnek türlerinin analizi: Limit Konusu. Türk Bilgisayar ve Matematik Eğitimi Dergisi, 9(1), 147-169.

Alkan, S., Güven, B. ve Y1lmaz, Ş. (2017). The types of examples teachers use in teaching function concept. Bayburt Eğitim Fakültesi Dergisi, 12(23), 367-384.

Arslan, S. ve Özpınar, İ. (2009). İlköğretim 6. sınıf matematik ders kitaplarının öğretmen görüssleri doğrultusunda değerlendirilmesi. Dicle Üniversitesi Ziya Gökalp Eğitim Fakültesi Dergisi, 12, 97-11.

Aydın, G. ve Balım, A.G. (2005). An interdisciplinary application based on constructivist approach: Teaching of energy topics. Ankara Üniversitesi Eğitim Bilimleri Fakültesi Dergisi, 38(2), 145-166. doi:10.1501/Egifak_0000000113

Aydoğmuş, E. (2008). Lise 2 fizik dersi iş-enerji konusunun öğretiminde 5E modelinin öğrenci başarısına etkisi (Yüksek lisans tezi). Selçuk Üniversitesi, Fen Bilimleri Enstitüsü, Konya. http://acikerisimarsiv.selcuk.edu.tr:8080/xmlui/handle/123456789/6295 adresinde erişilmiştir.

Ayvac1, H. Ş. ve Devecioğlu, Y. (2009, Mayıs). Illköğretim öğrencilerinin iş-güç-enerji konusunda sahip oldukları yanlı̧ anlamalar. First International Congress of Educational Research sunulan bildiri, Çanakkale-Türkiye. https://www.academia.edu/21787215/ Ayvac\%C4\%B1_H._\%C5\%9E._ve_Devecio\%C4\%9Flu_._2009_adresinden erişilmiştir.

Ayvacı, H. Ş. ve Devecioğlu, Y. (2013). 10. sınıf fizik ders kitabı ve kitaptaki etkinliklerin uygulanabilirliği hakkında öğretmen değerlendirmeleri. Amasya Üniversitesi Eğitim Fakültesi Dergisi, 2(2), 418-450.

Başer, N. (2012). Illköğretim ögretmenlerinin matematik ders kitaplarını kullanma yolları ve onların ögrencilerin matematik ders kitapların kullanma yolları ve matematik ders kitabı hakkındaki görüşleri (Yüksek lisans tezi). https://tez.yok.gov.tr/UlusalTezMerkezi/ adresinden erişilmiştir (Tez No: 321085).

Bills, L., Mason, J., Watson, A., \& Zaslavsky, O. (2006, July). Exemplification: The use of examples in teaching and learning mathematics. In J. Novotná, H. Moraová, M. Krátká, $\&$ N. Stehlíková (Eds.), Proceedings of the $30^{\text {th }}$ annual conference of the international group for the psychology of mathematics education. Prague, Czech Republic. Retrieved form https://files.eric.ed.gov/fulltext/ED496931.pdf\#page=236. 
Bozkurt, E. ve Sarıkoç, A. (2008). Fizik eğitiminde sanal laboratuvar, geleneksel laboratuvarın yerini tutabilir mi?. Selçuk Üniversitesi Ahmet Keleşoğlu Eğitim Fakültesi Dergisi, 25, 89-100.

Çakırlar, E., (2015). Ortaöğretim öğrencilerinin yenilenebilir enerji kaynakları konusundaki farkındalık düzeylerinin belirlenmesi (Yüksek lisans tezi). https://tez.yok.gov.tr/Ulusal TezMerkezi/adresinden erişilmiştir (Tez No: 394830).

Dayak, E. (1998). İlköğretim 5. sinıf matematik ders kitaplarının ĕgitim-öğretime uygunluğunun değerlendirilmesi (Yüksek lisans tezi). https://tez.yok.gov.tr/UlusalTezMerkezi/ adresinden erişilmiştir (Tez No: 71860).

Duman, T., Karakaya, N., Çakmak, M., Eray M. ve Özkan, M. (2001). Matematik 1-8. L. Küçükahmet (Ed.), Konu alanı ders kitabı inceleme kılavuzu içinde (ss. 10-40). Ankara: Nobel Yayın Dağıtım.

Eke, C., (2013, Eylül). Ortaöğretim fizik ders kitaplarında yer alan etkinliklerin bilimsel süreç becerileri bakımından analizi. I. Ulusal Fizik Eğitimi Kongresinde (UFEK 2013) sunulan bildiri, Ankara-Türkiye. http://www.egitim.hacettepe.edu.tr/belge/UFEK_2013_ bildiri_ ozetleri.pdf adresinden erişilmiştir.

Erduran Avc1, D., Kara, İ. ve Karaca, D. (2012). Fen bilgisi öğretmen adaylarının iş konusundaki kavram yanılgıları. Pamukkale Üniversitesi Eğitim Fakültesi Dergisi, 31(1), 27-39.

Ergin, S. (2011). Fizik eğitiminde 4mat öğretim yönteminin farklı ögrenme stillerine sahip lise ögrencilerinin iş, güç ve enerji konusundaki başarısına etkisi (Doktora tezi). https://tez.yok.gov.tr/UlusalTezMerkezi/ adresinden erişilmiştir (Tez No: 279722).

Esirgemez, M. (1995). Ilkokullarda matematik ders kitaplarının öğrenmeyi săglamadaki katkıları yönünden ögretmen görüşleri (Yüksek lisans tezi). https://tez.yok.gov.tr/ UlusalTez Merkezi/ adresinden erişilmiştir (Tez No: 47171).

Frankowicz, M., Maciejowska, I., Martinas, K., Radnóti, K, \& Rimai, A. (2008). Energy in school textbooks : A comparative study. Natural Science Education, 3, 34-41.

Gökbulut, Y. (2010). Sinıf öğretmeni adaylarının geometrik cisimler konusundaki pedagojik alan bilgileri (Doktora tezi). https://tez.yok.gov.tr/UlusalTezMerkezi/ adresinden erişilmiştir (Tez No: 279684).

Göze, N. (1999). Matematik zor değildir. Çă̆daş Ĕgitim Dergisi, 256, 33-37.

Gün, C. K. (2009). Ortaöğretim dokuzuncu sınıf matematik ders kitabina ilişkin öğretmen ve ögrenci görüşleri (Yüksek lisans tezi). https://tez.yok.gov.tr/UlusalTezMerkezi/ adresinden erişilmiştir (Tez No: 235186).

Işık, C. (2003). Illkögretim okullarının 7. sınıflarında okutulan matematik ders kitaplarının içerik, öğrenci seviyesine uygunluk ve anlamlı öğrenmeye katkısı yönünden değerlendirilmesi (Doktora tezi). https://tez.yok.gov.tr/UlusalTezMerkezi/ adresinden erişilmiştir (Tez No: 131575).

Işık, C. (2008). İlköğretim ikinci kademesinde matematik öğretmenlerinin matematik ders kitab1 kullanımını etkileyen etmenler ve beklentileri. Kastamonu Eğitim Dergisi, 16(1), 163176.

Karakuş, M., Türkkan, T. B. ve Karakuş, F. (2017). Fen bilgisi ve ilköğretim matematik öğretmenlerinin disiplinler arası yaklaşıma yönelik görüşlerinin belirlenmesi. Illköğretim Online, 16(2), 509-524. doi: 10.17051/ilkonline.2017.304714

Karamustafaoğlu, O., Yaman, S. ve Karamustafaoğlu, S. (2005). Fen ve teknoloji eğitiminde öğrenme ve öğretim materyalleri. T. Kesercioğlu ve M. Aydoğdu (Ed.), Fen ve ilköğretimde teknoloji öğretimi içinde (ss. 25-54) Ankara: Anı Yayıncılık.

Kavcar, N. (2012, Haziran). Ortaöğretim fizik 11 ders kitabının ögretmen adayları raporlarıyla değerlendirilmesi. X. Ulusal Fen Bilimleri ve Matematik Eğitimi Kongresinde (UFBMEK) sunulan bildiri. Niğde-Türkiye. http://kongre.nigde.edu.tr/xufbmek/ adresinden erişilmiştir.

Kavcar, N. ve Erdem, A. (2017). Fizik öğretim programları ile fizik ders kitaplarının proje tabanlı öğrenme açısından incelenmesi. Online Fen Eğitimi Dergisi, 2(1), 11-44. 
Kurnaz, M. A. (2011). Enerji konusunda model tabanlı ögrenme yaklaşımına göre tasarlanan ögrenme ortamlarının zihinsel model gelişimine etkisi (Doktora tezi). https://tez.yok.gov.tr/UlusalTezMerkezi/ adresinden erişilmiştir (Tez No: 300383).

Kılıç, A. ve Seven, S. (2002). Konu alanı ve ders kitabı incelemesi. Ankara, Pagema Yayıncılık.

Liu, G., \& Fang, N. (2016). Student misconceptions about force and acceleration in physics and engineering mechanics education. International Journal of Engineering Education, 32(1), 19-29.

Madanoğlu, N. (2015). 9. sınıf ögrrencilerinin iş ve enerji konusundaki kavramsal anlamalarının incelenmesi (Yüksek lisans tezi). https://tez.yok.gov.tr/UlusalTezMerkezi/ adresinden erişilmiştir (Tez No: 395591).

Michener, E. (1978). Understanding mathematics. Cognitive Science, 2, 361-383. doi:10.1207/s15516709 $\operatorname{cog} 0204 \_3$

Miles, M. B., \& Huberman, A. M. (1994). Qualitative data analysis: An expanded sourcebook. Beverly Hills: Sage Publications.

Milli Eğitim Bakanlığı [MEB]. (2018a). Ortaöğretim fizik 9 ders kitabı. Ankara: Milli Eğitim Bakanlığ Yayınları.

Milli Eğitim Bakanlığı [MEB]. (2018b). Ortaöğretim fizik 9 ders kitabl. Ankara: Tutku Yayıncllik.

Milli Eğitim Bakanlı̆̆ [MEB]. (2018c). Ortaöğretim fizik dersi (9, 10, 11 ve 12. sinıflar) ögretim programı. http://mufredat.meb.gov.tr/Dosyalar/201812103112910-orta\%C3\%B6 \%C4\%9Fretim_fizik_son.pdf adresinden erişilmiştir.

Milli Eğitim Bakanlığı, Talim ve Terbiye Kurulu Başkanlığı [MEB TTKB]. (2018). Ders kitapları ve eğitim araçları yönetmeliği. http://ttkb.meb.gov.tr/meb_iys_dosyalar/2016_ 01/12113913_yonetmelikderskitaplari.pdf adresinden erişilmiştir.

Oliveira, A. W., \& Brown, A. O. (2016). Exemplification in science instruction: Teaching and learning through examples. Journal of Research in Science Teaching, 53(5), 737-767.

Özgen, B. (1993). Türkiye'de ders kitapları sorunu ve çözüm yolları. Eğitim ve Bilim, 17(87), 48-59.

Sadoski, M. (2001). Resolving the effects of concreteness on interest, comprehension, and learning important ideas from text. Educational Psychology Review, 13(3), 263-281. doi: 10.1023/A:1016675822931

Senem, B. Y. ve Ery1lmaz, A. (2015). 9. sinıf fizik ders kitabında yer verilen bilimsel süreç becerileri. II. Ulusal Fizik Eğitimi Kongresinde (UFEK 2015) sunulan bildiri, Ankara. ufek.metu.edu.tr/kitaplar/ufek2015_ozetler.pdf adresinden erişilmiştir.

Taş, A. M. (2007). Yeni sosyal bilgiler ders kitaplarına ilişkin öğretmen görüşlerinin belirlenmesi. Selçuk Üniversitesi Sosyal Bilimler Enstitüsü Dergisi, 17, 519-532.

Tortop, H. S. (2012). Awareness and misconceptions of high school students about renewable energy resources and applications: Turkey case. Online Submission, 4(3) 1829-1840.

Viholainen, A., Partanen, M., Piiroinen, J., Asikainen, M., \& Hirvonen, P. E. (2015). The role of text-books in Finnish upper secondary school mathematics: theory, examples and exercises. Nordic Studies in Mathematics Education, 20(3-4), 157-178.

Watson, A, \& Mason, J. (2002). Student-generated examples in the learning of mathematics. Canadian Journal of Science, Mathematics and Technology Education, 2(2), 237-249. doi:10.1080/14926150209556516

Watson, A., \& Mason, J. (2005). Mathematics as a constructive activity: Learners generating examples. Mahwah, NJ: Erlbaum.

Yılmaz, A., Seçken, N. ve Morgil, İ. (1998). Lise 11. sınıf kimya 3 ders kitaplarının kimya eğitimine uygunluklarının araştırılması. Hacettepe Üniversitesi Eğitim Fakültesi Dergisi, 14, 73-83. 


\section{Extended Abstract}

\section{Introduction}

Books are one of the most basic tools used to convey information for generations (Adibelli, 2007). Textbooks have an important place in terms of being a concrete picture of the goals of the curriculum, being an important teaching tool that influences classroom teaching (Yilmaz, Seçken \& Morgil, 1998) and serving as a bridge between teachers and students in all kinds of school systems (Alkan \& Güven, 2018). Textbooks, especially help out teachers about following the curriculum and deciding what to do, how to do and when to do during the teaching process (Başer, 2012). It is important that information given in textbooks which provides students learning the subjects on their own, in a correct and sequential way (Duman et. 2001) should be in accord with the mental development of the students and present the subjects from concrete to abstract, simple to complex and easy to difficult (Esirgemez, 1995; Dayak, 1998; Gün, 2009; Sadoski, 2001).

As well as education of many courses, in physics education, besides the adaptation of the trio of teachers, students and educational technologies, textbooks' being suitable in terms of educational and visual design, language and expression are among the factors that affect success (Adibelli, 2007). When related literature was examined, it was determined that physics textbooks were evaluated in terms of the types of experiments, scientific process skills, activities and their suitability to the achievements in the curriculum (Aktamis, Feyzioglu, Ozenoglu-Kiremit \& Delioglu, 2010; Çepni, Ayvac1, Şenel-Çoruhlu \& Yamak, 2014; Eke, 2013; Senem \& Eryilmaz, 2015). However, examples and example types in the $9^{\text {th }}$ grade physics textbooks were not examined. Incomprehensible statements used in textbooks, complexity of examples which are not associated with daily life are among the reasons for the failure of the students (Göze, 1999; Işık, 2003; Özgen, 1993). The Ministry of National Education Textbooks and Educational Tools Regulation $(9 / 1 \mathrm{~b} ; 9 / 1 \mathrm{ç} ; 10 / 1 \mathrm{~b} ; 10 / 1 c ̧)$ emphasizes that the behavior, knowledge and skills that are intended to be acquired by students should be given according to their grade levels (MEB TTKB, 2018). In this context, it is important to evaluate the example types used in the textbooks and to compare the textbooks in terms of these example types.

Giving examples is an application that is at the center of effective science teaching (Oliveira \& Brown, 2016). Among the science courses, physics is the one that is difficult to understand and explain in terms of its subjects (Bozkurt \& Sarıkoç, 2008). In order to teach subjects more meaningfully, it is important to present examples in which students' prior knowledge are taken into account in learning environments, where transference is made from daily life, the transition between concepts is meaningful, and the relationships between concepts and events are emphasized (Ayvac1 \& Deveci, 2013). Examples are special cases used in explaining the situations that do not belong to the concepts, explaining the meanings of the rules or principles, and expressing the application of the procedures for these situations (Alkan, 2016). Examples can affect people's social experiences and create indelible cognitive and emotional effects on them (Oliveira \& Brown, 2016). Examples help to understand these concepts better by transforming the abstract concepts in our minds into a concrete structure (Gökbulut, 2010). In addition, they help to make the information about the concept more meaningful by playing an important role in understanding definitions and rules, classifying mathematical expressions and associating similar situations (Watson \& Mason, 2002). However, examples can prevent misconceptions that may occur by revealing situations that do not belong to the concept (Alkan, 2016). In an environment that is not enriched with example types, concepts can hardly be understood, and it is difficult for a single example type to express always all the meanings and properties of the concepts (Alkan, 2016; Alkan, Güven, \& Y1lmaz, 2017; Alkan \& Güven, 2018). 
This study aimed to determine and compare the example types used in energy unit in line with the learning outcomes in two different $9^{\text {th }}$ grade physics textbooks that belong to the 2018-2019 academic year. It is thought that it is important to examine the examples in the energy unit in terms of the fact that the students experience confusion about the concepts in the energy unit (Aydın \& Balım, 2005; Aydoğmuş, 2008; Ayvacı \& Devecioğlu, 2009; Ergin, 2011; Erduran Avc1, Kara \& Karaca, 2012; Kurnaz, 2012) and that the concepts related to energy are preliminary information for the units in the future (Madanoğlu, 2015).

\section{Method}

Document analysis method was used in accordance with the aim of the research. In the 20182019 academic year, 9th grade physics textbooks were examined as documents. In this sense, the textbooks were coded as Textbook 1 (TB1) and Textbook 2 (TB2). In order to determine the types of examples used in the $9^{\text {th }}$ grade physics textbooks in terms of energy, classification of examples (startup, standard, improving, non-example, extreme and counter examples) proposed by Alkan (2016) was taken into consideration.

\section{Result and Discussion}

In TB1, 65 examples were examined; 35 startup, 21 standard, 24 improving, 3 non-example and 5 counter examples were determined. In TB2, 62 examples were examined; 27 startup, 9 standard, 32 improving, 4 non-example and 4 counter examples were determined. No extreme examples were found in both textbooks. When example types were analyzed in terms of learning outcomes, it was seen that different numbers and different types of examples were used for each learning outcome.

According to the learning outcome 9.4.1.1., including sufficient startup examples in textbooks will meet the expectations in the curriculum better. It was observed that the number of startup examples in TB2 was higher than that of TB1, and non-examples were more included in TB2. This situation can attract the attention of students to the features related to the concepts and help them to focus on the concepts.

Learning outcome 9.4.1.2. points to use more improving example types in textbooks. The number of improving examples in TB1 is higher than that of TB2 so the students studying with this textbook will encounter more examples about the concept and can associate the expressed concepts with other concepts more easily.

In the learning outcome 9.4.2.1, which leads sub-titles within the concept of energy, examples of energy types (in the form of startup, standard and improving) should be used in the appropriate order (Alkan, 2016). It can be stated that the numbers and distribution of examples given in TB1 are more appropriate in this respect than that of TB2.

The counter examples in the textbooks ensure healthier formations of concept knowledge of the learners (Alkan \& Güven, 2018). However, there is only one counter example type in each textbook. Counter examples in the textbooks can draw attention to the presence of friction force in order to prevent the possible misconception that "all the work done can turn into the targeted energy".

In order to define the concept of basal metabolism related to the learning outcome 9.4.3.2, startup and standard examples should be included in the textbooks. The number of startup and standard examples in TB2 is higher than that of TB1. Textbooks play an important role in the success of educational programs so it is necessary to prepare textbooks according to an interdisciplinary approach (Arslan \& Özpınar, 2009; Karakuş, Türkkan \& Karakuş, 2017). 
Startup examples were given in TB1 regarding to learning outcome 9.4.1.1., in which the relationship between energy conversation and efficiency is expected to be explained through energy identity documents (MEB, 2018c). In a situation where students need to be aware of energy conservation and efficiency, it is thought that the number of examples related to this issue should be increased by different disciplines and daily life issues.

The historical development of the machines, which are thought to work without energy loss, has been examined in the light of learning outcome 9.4.4.2. It is seen that this learning outcome is tried to be explained by counter examples in textbooks. In this case, it has been found that it is appropriate to explain with counter examples that such perfect engine designs are not yet possible according to the laws of thermodynamics.

Learning outcome 9.4.5.1. emphasizes utilization of energy resources. It has been observed that the number of improving examples is more in TB2. This result may be due to the fact that, as stated by Çakırlar (2015), information on renewable energy sources is less discussed in secondary school 9th grade physics and biology textbooks.

The results obtained from this study were found only according to the examples mentioned in one unit. The examples in the other units in textbooks can also be examined for the purposes of the related learning outcomes. The textbooks recommended by the Ministry of National Education at different levels can be compared with the results of similar studies. In addition, the effects of the examples used in the textbooks on the students' conceptual understanding can be investigated. The types of examples used in textbooks, their convenience for the purpose of the learning outcomes can be researched and in line with the results of the research, improvements can be made in the textbooks. 